Comparison of Survival of Transfemoral Transcatheter Aortic Valve Implantation versus Surgical Aortic Valve Replacement for Aortic Stenosis in Low-Risk Patients without Coronary Artery Disease

Marko P.O. Virtanen MD , Juhani Airaksinen MD, PhD ,

Matti Niemelä MD, PhD, Teemu Laakso MD, Annastiina Husso MD, PhD, Maina P. Jalava MD , Tuomas Tauriainen MD, PhD , Pasi Maaranen MD , Eeva-Maija Kinnunen MD, PhD , Sebastian Dahlbacka MD, PhD , Stefano Rosato MSc, Mikko Savontaus MD, PhD ,

Tatu Juvonen MD, PhD, Mika Laine MD, PhD , Timo Mäkikallio MD, PhD, Antti Valtola MD, PhD , Peter Raivio MD, PhD , Markku Eskola MD, PhD , Fausto Biancari MD, PhD

PII:

DOI: S0002-9149(19)31293-7

Reference: https://doi.org/10.1016/j.amjcard.2019.11.002 AJC 24289

To appear in: The American Journal of Cardiology

Received date: $\quad 23$ September 2019

Revised date: $\quad 2$ November 2019

Accepted date: $\quad 5$ November 2019

Please cite this article as: Marko P.O. Virtanen MD, Juhani Airaksinen MD, PhD , Matti Niemelä MD, PhD, Teemu Laakso MD , Annastiina Husso MD, PhD, Maina P. Jalava MD , Tuomas Tauriainen MD, PhD , Pasi Maaranen MD , Eeva-Maija Kinnunen MD, PhD , Sebastian Dahlbacka MD, PhD , Stefano Rosato MSc , Mikko Savontaus MD, PhD , Tatu Juvonen MD, PhD , Mika Laine MD, PhD , Timo Mäkikallio MD, PhD, Antti Valtola MD, PhD , Peter Raivio MD, PhD , Markku Eskola MD, PhD , Fausto Biancari MD, PhD, Comparison of Survival of Transfemoral Transcatheter Aortic Valve Implantation versus Surgical Aortic Valve Replacement for Aortic Stenosis in Low-Risk Patients without Coronary Artery Disease, The American Journal of Cardiology (2019), doi: https://doi.org/10.1016/j.amjcard.2019.11.002

This is a PDF file of an article that has undergone enhancements after acceptance, such as the addition of a cover page and metadata, and formatting for readability, but it is not yet the definitive version of record. This version will undergo additional copyediting, typesetting and review before it is published in its final form, but we are providing this version to give early visibility of the article. Please note that, during the production process, errors may be discovered which could affect the content, and all legal disclaimers that apply to the journal pertain.

(C) 2019 Published by Elsevier Inc. 


\section{Comparison of Survival of Transfemoral Transcatheter Aortic Valve Implantation versus Surgical Aortic Valve Replacement for Aortic Stenosis in Low-Risk Patients without Coronary Artery Disease}

Marko P.O. Virtanen, ${ }^{\mathrm{a}} \mathrm{MD}$, Juhani Airaksinen, ${ }^{\mathrm{b}} \mathrm{MD}, \mathrm{PhD}$, Matti Niemelä, ${ }^{\mathrm{c}} \mathrm{MD}, \mathrm{PhD}$, Teemu Laakso, ${ }^{\mathrm{d}} \mathrm{MD}$, Annastiina Husso, ${ }^{\mathrm{e}} \mathrm{MD}$, PhD, Maina P. Jalava, ${ }^{\mathrm{b}} \mathrm{MD}$, Tuomas Tauriainen, ${ }^{\mathrm{f}}$ MD, PhD, Pasi Maaranen, ${ }^{a}$ MD, Eeva-Maija Kinnunen, ${ }^{\mathrm{d}} \mathrm{MD}, \mathrm{PhD}$, Sebastian Dahlbacka, ${ }^{\mathrm{d}}$ MD, PhD, Stefano Rosato, ${ }^{\mathrm{g}}$ MSc, Mikko Savontaus, ${ }^{\mathrm{b}} \mathrm{MD}, \mathrm{PhD}$, Tatu Juvonen, ${ }^{\mathrm{d}} \mathrm{MD}, \mathrm{PhD}$, Mika Laine, ${ }^{\mathrm{d}} \mathrm{MD}, \mathrm{PhD}$, Timo Mäkikallio, ${ }^{\mathrm{c}} \mathrm{MD}, \mathrm{PhD}$, Antti Valtola, ${ }^{\mathrm{e}} \mathrm{MD}, \mathrm{PhD}$, Peter Raivio, ${ }^{\mathrm{d}} \mathrm{MD}, \mathrm{PhD}$, Markku Eskola, ${ }^{\mathrm{a}} \mathrm{MD}, \mathrm{PhD}$, Fausto Biancari, ${ }^{\mathrm{b}, \mathrm{f}} \mathrm{MD}, \mathrm{PhD}$

${ }^{a}$ Heart Hospital, Tampere University Hospital and Faculty of Medicine and Health Technology, University of Tampere, Tampere, Finland;

${ }^{\mathrm{b}}$ Heart Center, Turku University Hospital, and Department of Surgery, University of Turku, Turku, Finland;

${ }^{c}$ Department of Internal Medicine, Oulu University Hospital, Oulu, Finland; ${ }^{\mathrm{d}}$ Heart Center, Helsinki University Hospital, Helsinki, Finland;

${ }^{\mathrm{e}}$ Heart Center, Kuopio University Hospital, Kuopio, Finland;

${ }^{\mathrm{f}}$ Department of Surgery, Oulu University Hospital and Research Unit of Surgery, Anesthesia and Intensive Care, Faculty of Medicine, University of Oulu, Oulu, Finland;

${ }^{\mathrm{g}}$ National Centre of Global Health, Istituto Superiore di Sanità, Rome, Italy.

Running Title: TAVI and SAVR in low-risk patients

Corresponding Author:

Prof. Fausto Biancari,

Heart Center,

Turku University Hospital,

PO Box 52, 20521 Turku

E-mail: faustobiancari@yahoo.it 


\section{Abstract}

Increasing data supports transcatheter aortic valve implantation (TAVI) as a valid option over surgical aortic valve replacement (SAVR) in the treatment for severe aortic stenosis (AS) also in patients with low operative risk. However, limited data exists on the outcome of TAVI and SAVR in low-risk patients without coronary artery disease (CAD). The FinnValve registry included data on 6463 patients who underwent TAVI or SAVR with bioprosthesis between 2008 and 2017. Herein, we evaluated the outcome of low operative risk as defined by STSPROM score $<3 \%$ and absence of $\mathrm{CAD}$, prior stroke and other relevant comorbidities. Only patients who underwent TAVI with third-generation prostheses and SAVR with Perimount Magna Ease or Trifecta prostheses were included in this analysis. The primary endpoints were 30-day and 3-year all-cause mortality. Overall, 1006 patients (175 TAVI patients and 831 SAVR patients) met the inclusion criteria of this analysis. Propensity score matching resulted in 140 pairs with similar baseline characteristics. Among these matched pairs, 30-day mortality was $2.1 \%$ in both TAVI and SAVR cohorts $(\mathrm{p}=1.00)$ and 3-year mortality was $17.0 \%$ after TAVI and $14.6 \%$ after SAVR $(\mathrm{p}=0.805)$. Lower rates of bleeding and atrial fibrillation, and shorter hospital stay were observed after TAVI. The need of new permanent pacemaker implantation and the incidence of early stroke did not differ between groups. In conclusion, TAVI using third-generation prostheses achieved similar early and mid-term survival compared to SAVR in low-risk patients without CAD.

Clinical trial registration: ClinicalTrials.gov Identifier: NCT03385915.

Key-words: TAVR; TAVI; transcatheter; aortic valve replacement; low risk. 
After the first-in-man transcatheter aortic valve implantation (TAVI) for severe aortic stenosis (AS), ${ }^{1}$ this treatment method has proven to be a valid alternative to surgical aortic valve replacement (SAVR) in intermediate- and high-risk AS patients. ${ }^{2-5}$ Based on the results of recent trials, ${ }^{6-8}$ the indication of TAVI has been expanded to low-risk patients. However, data on the long-term outcomes in these low-risk patients is still limited, particularly in those without coronary artery disease (CAD). Indeed, the prevalence of CAD is higher than $60 \%$ in intermediate-risk AS patients, whilst up to $28 \%$ of low-risk patients has concomitant CAD. ${ }^{4-}$ ${ }^{7,9}$ CAD may negatively affect the outcome after TAVI and SAVR, ${ }^{10-13}$ and it may be a major confounding factor in the analysis of the benefits and risks of TAVI and SAVR. Still, only a few studies compared these treatment methods in patients without significant CAD. ${ }^{14,15}$ This issue has been investigated in the present nationwide study.

\section{Methods}

The FinnValve registry is a nationwide study (ClinicalTrials.gov Identifier: NCT03385915), which includes data on consecutive and unselected patients who underwent TAVI or SAVR for severe AS, between January 2008 and October 2017, at all five Finnish University Hospitals. The study protocol was approved by the Institutional Review Boards of all participating centres. The FinnValve registry included data on patients who underwent primary TAVI or SAVR for AS with or without coronary revascularization. Data was collected retrospectively into a dedicated electronic case report form by physicians and trained research nurses. Data on mortality was obtained from the Finnish Population Register Centre and data on cardiovascular interventions was retrieved from the registry of the Finnish National Institute for Health and Welfare. Follow-up was considered complete for all patients, but for those not residing in Finland whose follow-up was truncated at the time of hospital discharge. The study followed the Strengthening the Reporting of Observational Studies in Epidemiology (STROBE) reporting guideline. ${ }^{16}$ 
This analysis included patients with low operative risk (Figure 1), which was defined as a Society of Thoracic Surgeons Predicted Risk of Mortality (STS-PROM) $<3 \%$ along with the following exclusion criteria: age $>85$ years, $\mathrm{CAD}$, prior coronary revascularization, prior cardiac surgery, stroke, estimated glomerular filtration rate $<30$ $\mathrm{mL} / \mathrm{min} / \mathrm{m}^{2}$, dialysis, functioning renal transplant, severe frailty, active malignancy, critical preoperative state, acute heart failure within 60 days from the index procedure, porcelain aorta, oxygen therapy, left ventricular ejection fraction $\leq 30 \%$, severe mitral valve regurgitation, non-transfemoral access for TAVI, and urgent/emergency procedure. The analysis was limited to third-generation TAVI prostheses (Sapien 3, Evolut R, Acurate Neo, Lotus) and SAVR pericardial prostheses (Perimount Magna Ease and Trifecta) in order to avoid any potential bias related to previous generation valve technology. CAD was defined as a stenosis of $50 \%$ or more in at least one of the main coronary arteries. Severe frailty was defined as Geriatric Status Scale 2-3 (GCS). ${ }^{17}$ Baseline variables were defined according to the European System for Cardiac Operative Risk Evaluation (EuroSCORE) II criteria. ${ }^{18}$

The primary outcomes of this study were 30-day and 3-year all-cause mortality. Secondary early outcomes were stroke, transfusion, reoperation for bleeding, paravalvular regurgitation, new permanent pacemaker implantation (PPI), acute kidney injury (AKI), new dialysis, conversion to cardiac surgery, coronary artery occlusion, aortic dissection/rupture, major vascular complication, atrial fibrillation and postoperative length of stay in the hospital where the index procedure was performed. Late secondary outcomes were repeat operation on the aortic valve prosthesis, prosthetic valve endocarditis, coronary revascularization and new PPI.

VARC-2 criteria $^{19}$ were applied for stroke, major vascular complication and perioperative bleeding. Severe bleeding was also defined according to European Coronary Artery Bypass Grafting (E-CABG) bleeding scores 2-3, i.e. transfusion of more than 4 units 
of red blood cells and/or reoperation for mediastinal and/or peripheral bleeding. ${ }^{20}$ AKI was defined according to the KDIGO criteria. $^{21}$

Statistical analyses were performed using Stata v. 15.1 (StataCorp LLC, Texas, USA) and SPSS v. 25.0 (IBM Corporation, New York, USA) statistical softwares.

Continuous variables are reported as means and standard deviations. Categorical variables are summarized as counts and percentages. The Mann-Whitney, Fisher's and Chi-square tests were used for univariate analysis in the unmatched population. A propensity score was estimated using a non-parsimonious logistic regression model including the following covariates: age, gender, body mass index, hemoglobin, estimated glomerular filtration rate, diabetes, pulmonary disease, extracardiac arteriopathy, New York Heart Association class 4 symptoms, left ventricular ejection fraction $\leq 50 \%$, atrial fibrillation, systolic pulmonary artery pressure, mitral valve regurgitation and prior pacemaker.

One-to-one propensity score matching was performed using the psmatch2 Stata module with a caliper width of 0.01 . Standardized differences lower than 0.10 were considered for adequate balance between the study cohorts. The paired t-test, the McNemar test and the Fleiss-Everitt test were used to assess the differences between preoperative variables and the early outcomes in the propensity score matched pairs. Differences in late mortality were evaluated by the Kaplan-Meier method with the log-rank test. Competing risk analysis with the Fine-Gray's test was performed for late non-fatal adverse events because patient's death might have hindered the observation of these events. Statistical significance was set at $\mathrm{p}<0.05$.

\section{Results}

Of 6463 patients included in the FinnValve registry, 1006 patients (mean age, 73.1 1 7.0 years; female gender, 53\%) fulfilled the inclusion criteria of the current analysis (Figure 1). TAVI 
was performed in 175 patients and SAVR in 831 patients. The mean follow-up of this series was 3.7 \pm 2.0 years (TAVI cohort, $2.2 \pm 0.9$ years; SAVR cohort $4.0 \pm 2.0$ years).

The baseline characteristics of the unmatched cohorts are presented in Table 1. Thirty-day mortality was $1.7 \%$ in TAVI and $1.6 \%$ in SAVR $(\mathrm{p}=0.885)$. Other early outcomes of the unmatched cohorts are presented in Table 2. Three-year all-cause mortality was higher after TAVI (16.6\%) compared to SAVR (6.8\%) (p=0.003; Table 3).

The propensity score matching resulted in 140 pairs. These cohorts had balanced baseline covariates except for hemoglobin and systolic pulmonary pressure whose standardized differences were slightly over 0.1 , without reaching statistically significance in paired tests (Table 1). The mean age of the patients was $76.5 \pm 6.8$ in the TAVI cohort and $76.9 \pm 4.7$ in the SAVR cohort $(\mathrm{p}=0.458)$. The predicted risk of operative mortality according to EuroSCORE II and STS score was similar between TAVI and SAVR. In the TAVI group, $62 \%$ of the patients received a balloon expandable prosthesis, $21 \%$ a self-expanding prosthesis and $16 \%$ a mechanically expandable prosthesis. In the surgical group, the Perimount Magna Ease bioprosthesis was implanted in 59\% of the patients and the Trifecta bioprosthesis in the others.

Three patients $(2.1 \%)$ died in both cohorts at 30 days after the procedure (Table 2). The late all-cause mortality was not different between the TAVI and SAVR cohorts (1year: $5.0 \%$ for both; 2 -year: $8.2 \%$ vs. $8.7 \%$; 3 -year: $17.0 \%$ vs. $14.6 \%, \mathrm{p}=0.805$, respectively) (Table 3, Figure 2).

Three patients $(2.1 \%)$ in both cohorts suffered stroke immediately after the procedure. Major vascular complication occurred in $7.9 \%$ of TAVI patients and in $0.7 \%$ SAVR patients $(\mathrm{p}=0.006)$. Similar rates of paravalvular regurgitation were observed in the study cohorts. Atrial fibrillation, bleeding and red blood cell transfusion were more frequent 
in the SAVR cohort (Table 2). Patients treated with TAVI had shorter hospital stay compared to the surgical cohort $(3.7 \pm 3.4$ days after TAVI and 7.5 \pm 3.4 days after SAVR; $p<0.0001)$. No statistically significant differences were observed in terms of AKI (Table 2). A new PPI was needed immediately after the procedure in 13 patients after TAVI $(9.8 \%)$ and in eight patients after SAVR $(6.1 \%)(\mathrm{p}=0.481)$. The rate of new PPI was numerically higher in the TAVI cohort compared to the SAVR cohort during follow-up, but the difference did not reach statistical significance (Table 3). Coronary revascularization and repeat aortic valve replacement were rare in these cohorts. No prosthetic valve endocarditis was observed in this series (Table 3).

\section{Discussion}

Our study group has previously reported similar results after TAVI and SAVR in patients with low operative risk from the nationwide FinnValve registry. ${ }^{22}$ In the present study, we report on updated survival along with prostheses-related adverse events of patients without CAD and other significant comorbidities who underwent isolated TAVI and SAVR. This selected patient population is expected to provide unbiased information on TAVI and SAVR device-related events, because the outcomes of interest are less likely affected by other confounders such as CAD, depressed ventricular function, cerebrovascular disease and renal failure. Indeed, our study cohort is somewhat similar to that of recent randomized controlled trials with low prevalence of atherosclerotic cardiovascular disease. ${ }^{6,7}$ Furthermore, the inclusion of patients who received newest generations of TAVI and SAVR prostheses may prevent bias related to less recent valve technology.

The main findings of this study are: 1) 30-day and 3-year survival were similar after TAVI or SAVR; 2) TAVI was associated with shorter hospital stay, lower rates of 
bleeding and atrial fibrillation compared to SAVR, but major vascular complications were more frequent after TAVI than after SAVR; 3) no differences in the incidence of early stroke and new PPI was observed between these two treatment strategies; 4) the intermediate-term risk for aortic valve reoperation is very low after TAVI and SAVR.

Thirty-day mortality was similar in the study cohorts $(2.1 \%)$. This means that, despite its less invasive nature, TAVI was not safer than SAVR in these very low-risk patients. In the propensity score matched cohorts, 3-year survival was $83 \%$ after TAVI and 85.4\% after SAVR, which demonstrates the clinical efficacy of both treatment methods at intermediate follow-up. Only patients who received most recent TAVI and SAVR prostheses were included in analysis, with low rates paravalvular regurgitation and structural valve deterioration.

Our results are balanced with those of previous studies. ${ }^{8}$ Randomized trials including low-risk patients and using composite primary outcomes confirmed TAVI as noninferior treatment over SAVR. ${ }^{6,7,14}$ Still there is no clear evidence of a survival benefit of TAVI over SAVR in low-risk populations. ${ }^{23}$ Early mortality in our study (30-day: $2.1 \%, 1$ year: 5.0\%) was slightly higher than in the PARTNER $3^{6}$ and the Evolut Low Risk Trial ${ }^{7}$ (30day: $0.4-0.5 \%$ for TAVI, 1.1-1.3\% for SAVR; 1-year: $1.0-2.4 \%$ for TAVI, $2.5-3.0 \%$ for SAVR), but similar to the results of the NOTION trial ${ }^{14}$ (30-day: $2.1 \%$ for TAVI, $3.7 \%$ for SAVR; 1-year: $4.9 \%$ for TAVI, 7.5\% for SAVR). Such differences are likely related to different age profiles of the study cohorts. The outcome of low-risk patients (STS score $<4 \%$ ) undergoing isolated aortic valve procedure from the German Aortic Valve Registry (GARY) showed a significantly lower 30-day mortality of patients undergoing TAVI compared to SAVR (1.7\% after transvascular TAVI vs. 3.0\% after SAVR, p=0.002), whilst 1-year survival was similar with these treatment methods (90.4\% after TAVI vs. $91.2 \%$ after SAVR, $\mathrm{p}=0.368) .{ }^{15}$ Non-randomized data is also available from the Low Risk Trial, which reported 
at 30-day nil mortality after TAVI and $1.7 \%$ mortality after SAVR $(\mathrm{p}=0.079) .{ }^{24}$ One-year survival rate was $97 \%$ in TAVI cohort. ${ }^{25}$ However, the patients in the Low Risk Trial were younger compared to other studies (age 73.6 years, STS 1.8\%). The longest follow-up of lowrisk patients' outcome is available from the NOTION trial, which demonstrated a 5-year survival of about $72 \%$ in the TAVI and SAVR cohorts. ${ }^{8}$

Our results indicate that, despite the low operative risk and the minimally invasive nature of TAVI, these patients are still exposed to a certain risk of early mortality and severe adverse events. Stroke, AKI stage 3, and severe bleeding were not infrequent after TAVI and might have had a negative impact on the longer-term survival after TAVI. ${ }^{26,27}$ Importantly, the early outcome of patients who underwent TAVI was affected by a significantly higher rate of major vascular complications, whilst blood transfusion was required frequently after SAVR (Tab. 2). Such differences are due to the different nature of these treatment methods. In fact, the risk of vascular complications at the access site is the Achille's heel of TAVI, even in these low-risk patients. On the contrary, SAVR may increase the risk of exposure to blood products due to significant bleeding from the operative field and to the marked hemodilution occurring during cardiopulmonary bypass. In this study, almost $70 \%$ of SAVR patients received blood transfusion, which might be partly explained by a policy of liberal perioperative blood transfusion adopted in our country. Still only $14 \%$ of patients required transfusion of more than four units of red blood cell. The risk of stroke after TAVI has remained relatively stable during past years with a rate of $2.0-2.5 \%$ as shown in a large database. ${ }^{28}$ The present study confirmed that such a risk of stroke exists also in low-risk patients, although previous studies reported on lower stroke rates. ${ }^{6,7,14}$

The risk of PPI was 9.8\% after TAVI, which can be considered satisfactory considering that about $60 \%$ of TAVI devices were balloon-expandable prostheses. ${ }^{29}$ The rate of new PPI after SAVR was $6.1 \%$ and remained relatively stable during 3-year follow-up 
(9.3\%). On the contrary, the rate of new PPI after TAVI increased to $14.6 \%$ at 3-years $(\mathrm{p}=0.082$ for TAVI vs. SAVR). Late coronary revascularization was rare in both the study cohorts and prosthetic valve endocarditis was not observed in this series.

The retrospective nature is the main limitation of this study. Secondly, the definition of low operative risk was based on STS score $<3 \%$ and by excluding patients with significant co-morbidities. Still, it is possible that some patients were incorrectly classified. Third, comparative analysis of the study cohorts is based on propensity score matching and its results are potentially biased by unmeasured confounders. Fourth, the small size and limited follow-up of this series prevent conclusive results on the efficacy and durability of TAVI in this patient population.

In conclusion, TAVI or SAVR with the most recent prostheses achieve similar early and mid-term outcome in low-risk patients without CAD. Potentially life-threatening complications can be expected in very low-risk patients despite the minimally invasive nature of transfemoral TAVI.

\section{Acknowledgments}

Disclosure of potential conflicts of interest: Dr. Mikko Savontaus is a proctor for Medtronic, the relationship is significant; Dr. Mika Laine is a proctor for Boston Scientific, the relationship is significant. The other coauthors do not have any conflict of interest related to this study.

Sources of funding and support: This study was not supported by any external funding. 


\section{References}

1. Cribier A, Eltchaninoff H, Bash A, Borenstein N, Tron C, Bauer F, Derumeaux G, Anselme F, Laborde F, Leon MB. Percutaneous transcatheter implantation of an aortic valve prosthesis for calcific aortic stenosis: First human case description. Circulation 2002;106:3006-3008.

2. Mack MJ, Leon MB, Smith CR, Miller DC, Moses JW, Tuzcu EM, Webb JG, Douglas PS, Anderson WN, Blackstone EH, Kodali SK, Makkar RR, Fontana GP, Kapadia S, Bavaria J, Hahn RT, Thourani VH, Babaliaros V, Pichard A, Herrmann HC, Brown DL, Williams M, Akin J, Davidson MJ, Svensson LG. 5-year outcomes of transcatheter aortic valve replacement or surgical aortic valve replacement for high surgical risk patients with aortic stenosis (PARTNER 1): a randomised controlled trial. Lancet 2015;385:2477-2484.

3. Gleason TG, Reardon MJ, Popma JJ, Deeb GM, Yakubov SJ, Lee JS, Kleiman NS, Chetcuti S, Hermiller JB, Heiser J, Merhi W, Zorn GL, Tadros P, Robinson N, Petrossian G, Hughes GC, Harrison JK, Conte J V., Mumtaz M, Oh JK, Huang J, Adams DH. 5-Year outcomes of self-expanding transeatheter versus surgical aortic valve replacement in highrisk patients. J Am Coll Cardiol 2018;72:2687-2696.

4. Leon MB, Smith CR, Mack MJ, Makkar RR, Svensson LG, Kodali SK, Thourani VH, Tuzcu EM, Miller DC, Herrmann HC, Doshi D, Cohen DJ, Pichard AD, Kapadia S, Dewey T, Babaliaros V, Szeto WY, Williams MR, Kereiakes D, Zajarias A, Greason KL, Whisenant BK, Hodson RW, Moses JW, Trento A, Brown DL, Fearon WF, Pibarot P, Hahn RT, Jaber WA, Anderson WN, Alu MC, Webb JG. Transcatheter or surgical aortic-valve replacement in intermediate-risk patients. N Engl J Med 2016;374:1609-1620.

5. Reardon MJ, Mieghem NM Van, Popma JJ, Kleiman NS, Søndergaard L, Mumtaz M, Adams DH, Deeb GM, Maini B, Gada H, Chetcuti S, Gleason T, Heiser J, Lange R, Merhi 
W, Oh JK, Olsen PS, Piazza N, Williams M, Windecker S, Yakubov SJ, Grube E, Makkar R, Lee JS, Conte J, Vang E, Nguyen H, Chang Y, Mugglin AS, Serruys PWJC, Kappetein AP. Surgical or transcatheter aortic-valve replacement in intermediate-risk patients. $N$ Engl J Med 2017;376:1321-1331.

6. Mack MJ, Leon MB, Thourani VH, Makkar R, Kodali SK, Russo M, Kapadia SR, Malaisrie SC, Cohen DJ, Pibarot P, Leipsic J, Hahn RT, Blanke P, Williams MR, McCabe JM, Brown DL, Babaliaros V, Goldman S, Szeto WY, Genereux P, Pershad A, Pocock SJ, Alu MC, Webb JG, Smith CR. Transcatheter aortic-valve replacement with a balloonexpandable valve in low-risk patients. N Engl J Med 2019;380:1695-1705.

7. Popma JJ, Deeb GM, Yakubov SJ, Mumtaz M, Gada H, O'Hair D, Bajwa T, Heiser JC, Merhi W, Kleiman NS, Askew J, Sorajja P, Rovin J, Chetcuti SJ, Adams DH, Teirstein PS, Zorn GL, Forrest JK, Tchétché D, Resar J, Walton A, Piazza N, Ramlawi B, Robinson N, Petrossian G, Gleason TG, Oh JK, Boulware MJ, Qiao H, Mugglin AS, Reardon MJ. Transcatheter aortic-valve replacement with a self-expanding valve in low-risk patients. $N$ Engl J Med 2019;380:1706-1715.

8. Thyregod HGH, Ihlemann N, Jørgensen TH, Nissen H, Kjeldsen BJ, Petursson P, Chang Y, Franzen OW, Engstrøm T, Clemmensen P, Hansen PB, Andersen LW, Steinbruüchel DA, Olsen PS, Søndergaard L. Five-year clinical and echocardiographic outcomes from the NOTION randomized clinical trial in patients at lower surgical risk. Circulation 2019;139:2714-2723.

9. Sankaramangalam K, Banerjee K, Kandregula K, Mohananey D, Parashar A, Jones BM, Jobanputra Y, Mick S, Krishnaswamy A, Svensson LG, Kapadia SR. Impact of coronary artery disease on 30-day and 1-year mortality in patients undergoing transcatheter aortic valve replacement: a meta-Analysis. J Am Heart Assoc 2017;6:e066092. 
10. Witberg G, Regev E, Chen S, Assali A, Barbash IM, Planer D, Vaknin-Assa H, Guetta V, Vukasinovic V, Orvin K, Danenberg HD, Segev A, Kornowski R. The prognostic effects of coronary disease severity and completeness of revascularization on mortality in patients undergoing transcatheter aortic valve replacement. JACC Cardiovasc Interv 2017;10:14281435.

11. Shamekhi J, Stundl A, Weber M, Mellert F, Welz A, Grube E, Nickenig G, Werner N, Sinning J-M. Impact of coronary artery disease in patients undergoing transfemoral transcatheter aortic valve implantation. Int J Cardiol 2017;245:215-221.

12. Stefanini GG, Stortecky S, Cao D, Rat-Wirtzler J, O’Sullivan CJ, Gloekler S, Buellesfeld L, Khattab AA, Nietlispach F, Pilgrim T, Huber C, Carrel T, Meier B, Jüni P, Wenaweser P, Windecker S. Coronary artery disease severity and aortic stenosis: clinical outcomes according to SYNTAX score in patients undergoing transcatheter aortic valve implantation. Eur Heart J 2014;35:2530-2540.

13. Beach JM, Mihaljevic T, Svensson LG, Rajeswaran J, Marwick T, Griffin B, Johnston DR, Sabik JF, Blackstone EH. Coronary artery disease and outcomes of aortic valve replacement for severe aortic stenosis. J Am Coll Cardiol 2013;61:837-848.

14. Thyregod HGH, Steinbrüchel DA, Ihlemann N, Nissen H, Kjeldsen BJ, Petursson P, Chang Y, Franzen OW, Engstrøm T, Clemmensen P, Hansen PB, Andersen LW, Olsen PS, Søndergaard L. Transcatheter versus surgical aortic valve replacement in patients with severe aortic valve stenosis. J Am Coll Cardiol 2015;65:2184-2194.

15. Bekeredjian R, Szabo G, Balaban Ü, Bleiziffer S, Bauer T, Ensminger S, Frerker C, Herrmann E, Beyersdorf F, Hamm C, Beckmann A, Möllmann H, Karck M, Katus HA, Walther T. Patients at low surgical risk as defined by the Society of Thoracic Surgeons Score undergoing isolated interventional or surgical aortic valve implantation: in-hospital data and 
1-year results from the German Aortic Valve Registry (GARY). Eur Heart J 2019;40:13231330.

16. Elm E von, Altman DG, Egger M, Pocock SJ, Gøtzsche PC, Vandenbroucke JP. The Strengthening the Reporting of Observational Studies in Epidemiology (STROBE) statement: guidelines for reporting observational studies. PLoS Med 2007;4:e296.

17. Rockwood K, Stadnyk K, MacKnight C, McDowell I, Hebert R, Hogan DB. A brief clinical instrument to classify frailty in elderly people. Lancet 1999;353:205-206.

18. Nashef SAM, Roques F, Sharples LD, Nilsson J, Smith C, Goldstone AR, Lockowandt U. EuroSCORE II. Eur J Cardio-Thoracic Surg 2012;41:734-745.

19. Kappetein AP, Head SJ, Généreux P, Piazza N, Mieghem NM van, Blackstone EH, Brott TG, Cohen DJ, Cutlip DE, Es G-A van, Hahn RT, Kirtane AJ, Krucoff MW, Kodali S, Mack MJ, Mehran R, Rodés-Cabau J, Vranckx P, Webb JG, Windecker S, Serruys PW, Leon MB. Updated standardized endpoint definitions for transcatheter aortic valve implantation: the Valve Academic Research Consortium-2 consensus document†. Eur Heart J 2012;33:24032418.

20. Biancari F, Ruggieri VG, Perrotti A, Svenarud P, Dalén M, Onorati F, Faggian G, Santarpino G, Maselli D, Dominici C, Nardella S, Musumeci F, Gherli R, Mariscalco G, Masala N, Rubino AS, Mignosa C, Feo M De, Corte A Della, Bancone C, Chocron S, Gatti G, Gherli T, Kinnunen E-M, Juvonen T. European multicenter study on Coronary artery Bypass Grafting (E-CABG registry): study protocol for a prospective clinical registry and proposal of classification of postoperative complications. J Cardiothorac Surg 2015;10:90.

21. Acute Kidney Injury Work Group. Section 2: AKI Definition. Kidney Int Suppl 2012;2:19-36. 
22. Virtanen MPO, Eskola M, Jalava MP, Husso A, Laakso T, Niemelä M, Ahvenvaara T, Tauriainen T, Maaranen P, Kinnunen E-M, Dahlbacka S, Jaakkola J, Vasankari T, Airaksinen J, Anttila V, Rosato S, D'Errigo P, Savontaus M, Juvonen T, Laine M, Mäkikallio T, Valtola A, Raivio P, Biancari F. Comparison of outcomes after transcatheter aortic Valve replacement vs surgical aortic valve replacement among patients with aortic stenosis at low operative risk. JAMA Netw Open 2019;2:e195742.

23. Kheiri B, Osman M, Bakhit A, Radaideh Q, Barbarawi M, Zayed Y, Golwala H, Zahr F, Stone GW, Bhatt DL. Meta-analysis of transcatheter aortic valve replacement in low-risk patients. Am J Med 2019. https://doi.org/10.1016/j.amjmed.2019.06.020. In press.

24. Waksman R, Rogers T, Torguson R, Gordon P, Ehsan A, Wilson SR, Goncalves J, Levitt R, Hahn C, Parikh P, Bilfinger T, Butzel D, Buchanan S, Hanna N, Garrett R, Asch F, Weissman G, Ben-Dor I, Shults C, Bastian R, Craig PE, Garcia-Garcia HM, Kolm P, Zou Q, Satler LF, Corso PJ. Transcatheter aortic valve replacement in low-risk patients with symptomatic severe aortic stenosis. J Am Coll Cardiol 2018;72:2095-2105.

25. Waksman R, Corso PJ, Torguson R, Gordon P, Ehsan A, Wilson SR, Goncalves J, Levitt R, Hahn C, Parikh P, Bilfinger T, Butzel D, Buchanan S, Hanna N, Garrett R, Buchbinder M, Asch F, Weissman G, Ben-Dor I, Shults C, Bastian R, Craig PE, Ali S, Garcia-Garcia HM, Kolm P, Zou Q, Satler LF, Rogers T. TAVR in Low-risk patients. JACC Cardiovasc Interv 2019;12:901-907.

26. Arnold S V., Zhang Y, Baron SJ, McAndrew TC, Alu MC, Kodali SK, Kapadia S, Thourani VH, Miller DC, Mack MJ, Leon MB, Cohen DJ. Impact of short-term complications on mortality and quality of life after transcatheter aortic valve replacement. JACC Cardiovasc Interv 2019;12:362-369.

27. Maaranen P, Husso A, Tauriainen T, Lahtinen A, Valtola A, Ahvenvaara T, Virtanen M, 
Laakso T, Kinnunen E-M, Dahlbacka S, Juvonen T, Mäkikallio T, Jalava MP, Jaakkola J, Airaksinen J, Vasankari T, Rosato S, Savontaus M, Laine M, Raivio P, Niemelä M, Mennander A, Eskola M, Biancari F. Blood transfusion and outcome after transfemoral transcatheter aortic valve replacement. J Cardiothorac Vasc Anesth 2019;33:2949-2959.

28. Huded CP, Tuzcu EM, Krishnaswamy A, Mick SL, Kleiman NS, Svensson LG, Carroll J, Thourani VH, Kirtane AJ, Manandhar P, Kosinski AS, Vemulapalli S, Kapadia SR. Association between transcatheter aortic valve replacement and early postprocedural stroke. JAMA - J Am Med Assoc 2019;321:2306-2315.

29. Rosendael PJ van, Delgado V, Bax JJ. Pacemaker implantation rate after transcatheter aortic valve implantation with early and new-generation devices: a systematic review. Eur Heart J 2018;39:2003-2013.

\section{Legends to figures}

Figure 1. Study flow-chart.

Figure 2. Kaplan-Meier estimate of survival in propensity score matched pairs of low-risk patients with severe aortic stenosis without coronary artery disease who underwent transcatheter (TAVI) or surgical aortic valve replacement (SAVR). 
Table 1. Characteristics of unmatched and propensity score matched patients.

\begin{tabular}{|c|c|c|c|c|c|c|c|c|}
\hline \multirow[b]{2}{*}{ Variable } & \multicolumn{2}{|c|}{ Unmatched cohorts } & \multicolumn{6}{|c|}{ Propensity score matched cohorts } \\
\hline & $\begin{array}{l}\text { TAVI } \\
(\mathrm{n}=175)\end{array}$ & $\begin{array}{l}\text { SAVR } \\
(\mathrm{n}=831)\end{array}$ & $\begin{array}{l}\text { Standardized } \\
\text { difference }\end{array}$ & p-value & $\underset{(n=140)}{\text { TAVI }}$ & $\begin{array}{l}\text { SAVR } \\
(\mathrm{n}=140)\end{array}$ & $\begin{array}{l}\text { Standardized } \\
\text { difference }\end{array}$ & p-value \\
\hline Age (years) & $77.4 \pm 6.4$ & $72.2 \pm 6.8$ & 0.790 & $<0.0001$ & $76.5 \pm 6.8$ & $76.9 \pm 4.7$ & 0.068 & 0.458 \\
\hline Women & $101(57.7 \%)$ & $431(51.9 \%)$ & 0.117 & 0.159 & $79(56.4 \%)$ & $75(53.6 \%)$ & 0.057 & 0.731 \\
\hline Body mass index $\left(\mathrm{kg} / \mathrm{m}^{2}\right)$ & $29 \pm 5$ & $28 \pm 5$ & 0.151 & 0.114 & $29 \pm 5$ & $29 \pm 5$ & 0.073 & 0.555 \\
\hline Hemoglobin (mg/L) & $130 \pm 16$ & $135 \pm 13$ & 0.370 & $<0.0001$ & $130 \pm 16$ & $129 \pm 14$ & 0.113 & 0.364 \\
\hline $\begin{array}{l}\text { Estimated glomerular filtration rate } \\
\left(\mathrm{ml} / \mathrm{min} / 1.73 \mathrm{~m}^{2}\right)\end{array}$ & $75 \pm 21$ & $80 \pm 19$ & 0.261 & 0.001 & $75 \pm 21$ & $74 \pm 20$ & 0.038 & 0.764 \\
\hline Diabetes mellitus & $46(26.3 \%)$ & $170(20.5 \%)$ & 0.138 & 0.088 & $35(25.0 \%)$ & $37(26.4 \%)$ & 0.033 & 0.883 \\
\hline Pulmonary disease & $30(17.1 \%)$ & $90(10.8 \%)$ & 0.183 & 0.019 & $22(15.7 \%)$ & $26(18.6 \%)$ & 0.076 & 0.643 \\
\hline Extracardiac arteriopathy & $13(7.4 \%)$ & $46(5.5 \%)$ & 0.077 & 0.333 & $11(7.9 \%)$ & $10(7.1 \%)$ & 0.027 & 1.000 \\
\hline Ejection fraction $\leq 50 \%$ & $29(16.7 \%)$ & $88(10.6 \%)$ & 0.178 & 0.023 & $19(13.6 \%)$ & $21(15.0 \%)$ & 0.048 & 0.860 \\
\hline Atrial fibrillation & $63(36.0 \%)$ & $139(16.7 \%)$ & 0.448 & $<0.0001$ & $47(33.6 \%)$ & $46(32.9 \%)$ & 0.015 & 1.000 \\
\hline New York Heart Association Class 4 & $1(0.6 \%)$ & $5(0.6 \%)$ & 0.004 & 1.000 & $1(0.7 \%)$ & $2(1.4 \%)$ & 0.069 & 1.000 \\
\hline Systolic pulmonary artery pressure $(\mathrm{mmHg})$ & & & 0.089 & 0.519 & & & 0.166 & 0.933 \\
\hline $31-55$ & $58(33.1 \%)$ & $286(34.4 \%)$ & & & $45(32.1 \%)$ & $39(27.9 \%)$ & & \\
\hline$>55$ & $9(5.1 \%)$ & $28(3.4 \%)$ & & & $6(4.3 \%)$ & $11(7.9 \%)$ & & \\
\hline Mitral regurgitation & & & 0.437 & $<0.0001$ & & & 0.047 & 0.944 \\
\hline Mild & $54(33.3 \%)$ & $174(21.9 \%)$ & & & $46(32.9 \%)$ & $43(30.7 \%)$ & & \\
\hline Moderate & $14(8.6 \%)$ & $15(1.9 \%)$ & & & $7(5.0 \%)$ & $7(5.0 \%)$ & & \\
\hline Prior permanent pace-maker & $12(6.9 \%)$ & $30(3.6 \%)$ & 0.146 & 0.051 & $7(5.0 \%)$ & $8(5.7 \%)$ & 0.032 & 1.000 \\
\hline $\begin{array}{l}\text { European System for Cardiac Operative Risk } \\
\text { Evaluation II }(\%)\end{array}$ & $2.3 \pm 1.0$ & $1.6 \pm 0.8$ & 0.717 & $<0.0001$ & $2.1 \pm 0.9$ & $2.1 \pm 1.1$ & 0.020 & 0.398 \\
\hline Society of Thoracic Surgeons score (\%) & $2.1 \pm 0.6$ & $1.6 \pm 0.6$ & 0.832 & $<0.0001$ & $2.0 \pm 0.6$ & $2.0 \pm 0.6$ & 0.089 & 0.845 \\
\hline
\end{tabular}

TAVI, transcatheter aortic valve implantation; SAVR, surgical aortic valve replacement. Values are number $(\%)$ or mean \pm standard deviation. 
Table 2. Early outcomes of unmatched and propensity score matched patients.

\begin{tabular}{|c|c|c|c|c|c|c|}
\hline \multirow[b]{2}{*}{ Variable } & \multicolumn{2}{|c|}{ Unmatched cohorts } & \multicolumn{4}{|c|}{ Propensity score matched pairs } \\
\hline & $\begin{array}{c}\text { TAVI } \\
(\mathrm{n}=175)\end{array}$ & $\begin{array}{c}\text { SAVR } \\
(\mathrm{n}=831)\end{array}$ & p-value & $\begin{array}{c}\text { TAVI } \\
(\mathrm{n}=140)\end{array}$ & $\begin{array}{c}\text { SAVR } \\
(\mathrm{n}=140)\end{array}$ & p-value \\
\hline 30-day death & $3(1.7 \%)$ & $13(1.6 \%)$ & 0.885 & $3(2.1 \%)$ & $3(2.1 \%)$ & 1.000 \\
\hline Stroke & $4(2.3 \%)$ & $20(2.4 \%)$ & 1.000 & $3(2.1 \%)$ & $3(2.1 \%)$ & 1.000 \\
\hline Conversion to cardiac surgery & $2(1.1 \%)$ & - & - & $2(1.4 \%)$ & - & - \\
\hline Deep sternal wound infection/mediastinitis & 0 & $11(1.3 \%)$ & 0.228 & 0 & $2(1.4 \%)$ & 0.500 \\
\hline Coronary revascularization & 0 & $6(0.7 \%)$ & 0.597 & 0 & $1(0.7 \%)$ & 1.000 \\
\hline Coronary ostium occlusion & 0 & $3(0.4 \%)$ & 1.000 & 0 & $1(0.7 \%)$ & 1.000 \\
\hline Aortic dissection/rupture & $1(0.1 \%)$ & $4(0.5 \%)$ & 1.000 & $1(0.7 \%)$ & 0 & 1.000 \\
\hline Major vascular complication & $15(8.6 \%)$ & $7(0.7 \%)$ & $<0.0001$ & $11(7.9 \%)$ & $1(0.7 \%)$ & 0.006 \\
\hline Red blood cell transfusion & $17(9.9 \%)$ & $439(53.9 \%)$ & $<0,0001$ & $13(9.6 \%)$ & $94(69.1 \%)$ & $<0.0001$ \\
\hline Red blood cell transfusion (units) & $0.4 \pm 1.7$ & $1.7 \pm 2.5$ & $<0.0001$ & $0.4 \pm 1.8$ & $2.3 \pm 2.7$ & $<0.0001$ \\
\hline Red blood cell transfusion $>4$ units & $3(1.8 \%)$ & $84(10.3 \%)$ & $<0.0001$ & $3(2.2 \%)$ & $19(14.0 \%)$ & $<0.0001$ \\
\hline Resternotomy/thoracotomy for bleeding & $2(1.1 \%)$ & $65(7.8 \%)$ & $<0.0001$ & $2(1.4 \%)$ & $11(7.9 \%)$ & 0.022 \\
\hline E-CABG bleeding grades $2-3^{\mathrm{a}}$ & $9(5.3 \%)$ & $110(13.5 \%)$ & 0.003 & $7(5.1 \%)$ & $23(16.9 \%)$ & 0.002 \\
\hline VARC-2 bleeding & & & $<0.0001$ & & & $<0.0001$ \\
\hline Major bleeding & $36(20.8 \%)$ & $360(43.3 \%)$ & & $27(19.6 \%)$ & $68(48.6 \%)$ & \\
\hline Life-threatening or disabling & $9(5.2 \%)$ & $415(49.9 \%)$ & & $7(5.1 \%)$ & $59(42.1 \%)$ & \\
\hline Acute kidney injury grades $2-3$ & $4(2.3 \%)$ & $31(3.8 \%)$ & 0.494 & $4(2.9 \%)$ & $7(5.0 \%)$ & 0.549 \\
\hline New renal replacement therapy & 0 & $11(1.3 \%)$ & 0.228 & 0 & $3(2.1 \%)$ & 0.250 \\
\hline Paravalvular regurgitation & & & $<0.0001$ & & & 0.431 \\
\hline Mild & $16(9.1 \%)$ & $46(5.5 \%)$ & & $13(9.3 \%)$ & $9(6.4 \%)$ & \\
\hline Moderate & $5(2.9 \%)$ & $1(0.1 \%)$ & & $3(2.1 \%)$ & $1(0.7 \%)$ & \\
\hline Severe & 0 & $1(0.1 \%)$ & & 0 & 0 & \\
\hline Atrial fibrillation & $56(32.0 \%)$ & $430(51.7 \%)$ & $<0.0001$ & $43(30.7 \%)$ & $82(58.6 \%)$ & $<0.0001$ \\
\hline Permanent pacemaker, ${ }^{\mathrm{b}}$ & $16(9.8 \%)$ & $30(3.7 \%)$ & 0.001 & $13(9.8 \%)$ & $8(6.1 \%)$ & 0.481 \\
\hline Hospital stay (days) & $3.8 \pm 3.1$ & $7.2 \pm 4.3$ & $<0.0001$ & $3.7 \pm 3.2$ & $7.5 \pm 3.4$ & $<0.0001$ \\
\hline
\end{tabular}

TAVI, transcatheter aortic valve implantation; SAVR, surgical aortic valve replacement; E-CABG, European Coronary Artery Bypass Grafting study; VARC, Valve Academic Research

Consortium; ${ }^{\mathrm{a}}$, it includes also intervention for peripheral bleeding; $;$, it excludes patients with prior pacemaker implantation. Values are number $(\%)$ or mean \pm standard deviation. 
Table 3. Late outcomes of unmatched and propensity score matched patients.

\begin{tabular}{|c|c|c|c|c|c|c|}
\hline \multirow[b]{2}{*}{ Variable } & \multicolumn{2}{|c|}{ Unmatched cohorts } & \multicolumn{4}{|c|}{ Propensity score matched pairs } \\
\hline & $\begin{array}{c}\text { TAVI } \\
(\mathrm{n}=175)\end{array}$ & $\begin{array}{c}\text { SAVR } \\
(\mathrm{n}=831)\end{array}$ & $\mathrm{p}$-value & $\begin{array}{c}\text { TAVI } \\
(\mathrm{n}=140)\end{array}$ & $\begin{array}{c}\text { SAVR } \\
(\mathrm{n}=140)\end{array}$ & p-value \\
\hline All-cause mortality & & & 0.003 & & & 0.805 \\
\hline 1-year & $4.0 \%$ & $3.4 \%$ & & $5.0 \%$ & $5.0 \%$ & \\
\hline 2-year & $8.6 \%$ & $4.5 \%$ & & $8.2 \%$ & $8.7 \%$ & \\
\hline 3 -year & $16.6 \%$ & $6.8 \%$ & & $17.0 \%$ & $14.6 \%$ & \\
\hline Coronary revascularization & & & 0.858 & & & 0.679 \\
\hline 1-year & $0.6 \%$ & $1.1 \%$ & & $0.7 \%$ & $0.7 \%$ & \\
\hline 2-year & $0.6 \%$ & $1.3 \%$ & & $0.7 \%$ & $0.7 \%$ & \\
\hline 3 -year & $2.6 \%$ & $1.5 \%$ & & & $1.7 \%$ & \\
\hline Prosthetic valve endocarditis & & & & & & - \\
\hline 1 -year & 0 & 0 & & 0 & 0 & \\
\hline 2-year & 0 & 0 & & 0 & 0 & \\
\hline 3-year & 0 & 0 & & 0 & 0 & \\
\hline Repeat aortic valve replacement & & & - & & & - \\
\hline 1-year & 0 & $0.2 \%$ & & 0 & $0.8 \%$ & \\
\hline 2-year & 0 & $0.6 \%$ & & 0 & $0.8 \%$ & \\
\hline 3-year & 0 & $0.8 \%$ & & 0 & $0.8 \%$ & \\
\hline New pace-maker implantation & & & $<0.0001$ & & & 0.082 \\
\hline 1-year & $13.3 \%$ & $4.1 \%$ & & $13.8 \%$ & $6.2 \%$ & \\
\hline 2-year & $15.4 \%$ & $5.1 \%$ & & $14.6 \%$ & $6.2 \%$ & \\
\hline 3-year & $15.4 \%$ & $6.0 \%$ & & $14.6 \%$ & $9.3 \%$ & \\
\hline
\end{tabular}


Figure 1.

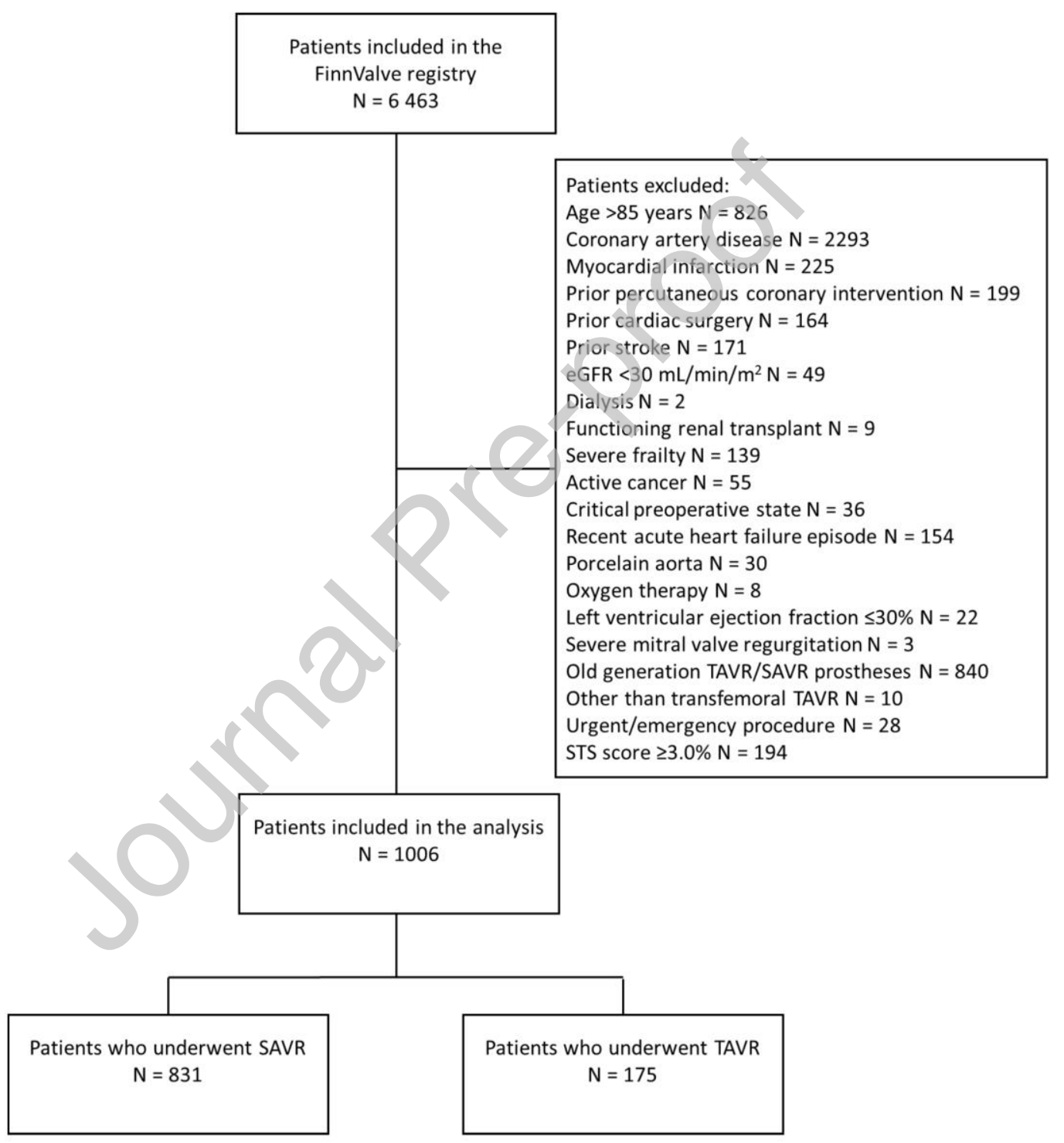


Figure 2.

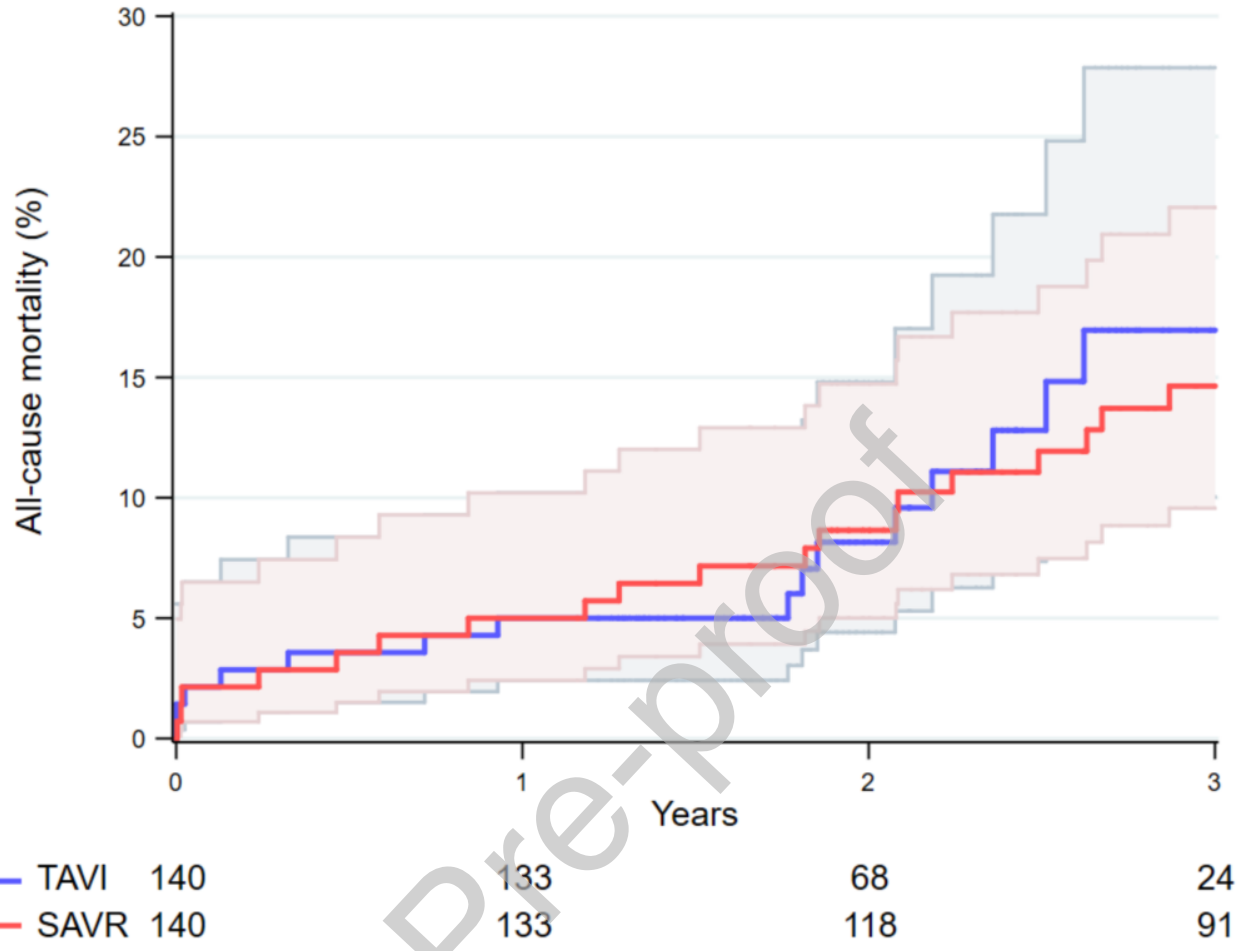

